\title{
Evaluation of affinity of bioactive isolates from various coffee extracts through binding with PPAR- $\gamma$ with the use of isothermal titration calorimetry and docking simulation to prevent antidiabetic effects
}

\author{
Joanna Grzelczyk ${ }^{1}$ (D) Grażyna Budryn ${ }^{1}$ (D) . Horacio Pérez-Sánchez ${ }^{2}$ (D)
}

Received: 30 August 2019 / Accepted: 6 May 2020 / Published online: 19 May 2020

(c) The Author(s) 2020

\begin{abstract}
Peroxisome proliferator-activated receptor- $\gamma(\operatorname{PPAR}-\gamma)$ is a major receptor responsible for the pathogenesis of type 2 diabetes mellitus (T2DM). Deficiency in the human body of ligands binding to PPAR- $\gamma$ causes the disorder of expression of many genes in adipose tissue and contributes to reducing tissue sensitivity to insulin, making it difficult to maintain glucose homeostasis, which consequently leads to T2DM. Therefore, natural non-toxic PPAR- $\gamma$ ligands are sought. The aim of the research was to assess the affinity of single hydroxycinnamic or chlorogenic acids, coffee extracts and bioactive isolates from various coffee extracts of green, light and dark roasted Arabica and Robusta for PPAR- $\gamma$. This allows determining what type of coffee extract or its fraction can be used for therapy of T2DM. The research was carried out by means of isothermal titration calorimetry and molecular docking simulation. The studies have shown that caffeine and dihydrocaffeic acid had the highest affinity for PPAR- $\gamma$, which amounted $\Delta G=-39.46 \mathrm{~kJ} \mathrm{~mol}^{-1}$ and $-33.60 \mathrm{~kJ} \mathrm{~mol}^{-1}$, respectively.
\end{abstract}

Keywords PPAR- $\gamma \cdot$ ITC $\cdot$ Docking simulation $\cdot$ Coffee $\cdot$ Antidiabetic

\section{Introduction}

The high percentage of the world's population suffers from metabolic disorders such as diabetes mellitus (DM) or is at high risk of becoming ill. The pathogenesis of diabetes is the disruption of insulin secretion by the pancreas, and this is an incurable disease, slowly debilitating the body, and is associated with taking medication for life. There are three types of diabetes, namely I, II and gestational diabetes, which have a different development of the disease [1-3]. Type I diabetes is a genetic disease and affects young people, and the main feature of the development of the disease is the destruction of insulin-producing pancreatic $\beta$-cells by the immune system, until the pancreas stops producing insulin completely,

Joanna Grzelczyk

joanna.grzelczyk@dokt.p.lodz.pl

1 Institute of Food Technology and Analysis, Faculty of Biotechnology and Food Sciences, Lodz University of Technology, Lodz, Poland

2 Bioinformatics and High-Performance Computing Research Group (BIO-HPC), Computer Engineering Department, Universidad Católica de Murcia (UCAM), Guadalupe, Murcia, Spain resulting in increased blood glucose, a condition called "hyperglycemia" [4, 5]. Another case is type II diabetes mellitus (T2DM), the development of which we can affect. The factors that influence the cause of the disease are genetics; however, most often these are environmental factors such as a poorly varied diet that leads to obesity. In type II diabetes, compared to the first the course of the disease takes place in stages, where insulin secretion is impaired [6-8]. To keep blood glucose levels normal, the pancreatic $\beta$-cells produce an increased amount of insulin, which they secrete, until the pancreas is completely exhausted and destroyed, the process of which is called insulin resistance $[9,10]$. That is why, it is important to maintain normal glucose homeostasis and increase the insulin sensitivity of peripheral tissues [11].

Peroxisome proliferator-activated receptor- $\gamma(\operatorname{PPAR}-\gamma)$ is a hormone mainly responsible for gene expression involved in fats and carbohydrates metabolism, which causes increasing the level of insulin sensitivity, contributing to maintenance of glucose homeostasis $[12,13]$. It has three types of gamma isoforms: $\gamma 1, \gamma 2$ and $\gamma 3$, of which the PPAR $\gamma 2$ protein is 30 amino acids shorter at the nitrogen terminus [14, 15]. The activation of PPAR- $\gamma$ by their ligands induces the expression of proteins, such as lipoprotein lipase, reduces inflammation and thereby controls fatty acid metabolism, 
regulating fatty acid transport and adipogenesis $[16,17]$. Excessive lipid accumulation in pancreatic $\beta$-cells is a consequence of elevated concentration of free fatty acids, which disturbs the secretion of adiponectin and leads to insulin resistance [18-20]. Synthetic PPAR- $\gamma$ agonists, such as thiazolidinediones, are used in antidiabetic therapy. The use of this substance for a long time causes negative effects on the human body, among others swelling and inflammation. That is why, natural ligands are sought and we used in our research bioactive compounds contained in coffee, mostly polyphenols, which are characterized by antioxidant properties and are not toxic to our body [21-24]. To assess the possible degree of PPAR- $\gamma$ activation and select the most stable complexes of compounds contained in coffee with the PPAR- $\gamma$ receptor and to determine the type of bonds, we used isothermal titration calorimetry (ITC) and performed molecular simulation of docking.

\section{Materials and methods}

\subsection{Chemical and reagents}

15 -Deoxy- $\Delta 12,14$-prostaglandin $\quad \mathrm{J} 2$ ( $\geq 95 \%)$, 5-O-caffeoylquinic acid ( $\geq 99 \%), 3$ - $O$-caffeoylqunic acid ( $\geq 99 \%)$, 4- $O$-caffeoylqunic acid ( $\geq 99 \%)$, caffeic acid ( $\geq 99 \%)$, caffeine $(\geq 99 \%)$, ferulic acid $(\geq 99 \%), 3,5-O$-dicaffeoylquinic acid $(\geq 99 \%)$ and 4,5-O-dicaffeoylquinic acid ( $\geq 99 \%)$, dihydrocaffeic acid ( $\geq 99 \%$ ), PPAR- $\gamma$, ligand-binding domain (204-477) and GST-tagged human (concentration $50 \mu \mathrm{g} \mathrm{mL}^{-1}$ ) were purchased from Sigma-Aldrich (St. Louis, MO, USA) and nylon filters from Chromacol (Herts, UK).

\section{Roasting and preparing coffee extract and its fractions}

The raw materials used for research were green Arabica (Coffee arabica L.), variety Brazil Cerrado, and Robusta (Coffea canephora L.), variety India Cherry coffee beans, purchased from Bero Polska (Gdynia, Poland). Roasting of the coffee beans was conducted in an air cyclone system (vertiflow ${ }^{\circledR}$ patent) with a load capacity of $2.5 \mathrm{~kg}$ (Roaster 102, Selmi group, Santa Vittoria d'Alba) at $230^{\circ} \mathrm{C}$ for $6 \mathrm{~min}$ to achieve dark roasting and at $195^{\circ} \mathrm{C}$ for 6 min to achieve light roasting. Green, light and dark roasted beans of Robusta and Arabica coffees were ground and sieved (480-680 $\mu \mathrm{m})$, and aqueous extracts were obtained by pressure boiling at $110{ }^{\circ} \mathrm{C}$ for $10 \mathrm{~min}$ at $1: 5.75(\mathrm{~m} / \mathrm{m})$ ratio of coffee to water (PS-5682 Vienna, Austria); in the next step, these suspensions were chilled in a water bath at $40{ }^{\circ} \mathrm{C}$ for $20 \mathrm{~min}$, filtered under vacuum pump (KNF 18,035.3 N, Neuberger, NJ, USA) and freeze-dried. The freeze-dried extracts were purified and fractionated by centrifugal separation chromatography (Spot Prep II, Ancem, Poland). The system used for CPC consisted of hydrophilic and hydrophobic (two-phase solvent) phases; three solvents were used for this purpose: water, ethanol and ethyl acetate. The elution of fractions of dichlorogenic acids (3,4-, 3,5- and 4,5-O-caffeoylquinic acid) from the separated coffee extracts took place between 19 and $24 \mathrm{~min}$ (more hydrophobic fractions) and of monochlorogenic acids (caffeic, ferulic, 3-, 4-, 5- $O$-caffeoylquinic, 3-, 4- and 5-O-feruloylquinic acid) between 27 and $31 \mathrm{~min}$ (more hydrophilic fractions) of the analysis, confirmed by high UV absorption at $320 \mathrm{~nm}$ and of caffeine between 25 and 26 min with high absorption at $280 \mathrm{~nm}$ (Fig. 1). Fractions were collected, concentrated, re-lyophilized and stored at $-25{ }^{\circ} \mathrm{C}$ for calorimetric research [25]. The obtained fractions were partially purified but completely homogeneous
Fig. 1 Centrifugal partition chromatogram (CPC) of crude aqueous green (GCE) coffee extracts at $320 \mathrm{~nm}$ (dashed line) and $280 \mathrm{~nm}$ (solid line), fractions: $17-23.5 \mathrm{~min}-$ monochlorogenic acids, 23.5$28 \mathrm{~min}$ - caffeine, 28-32 mindichlorogenic acids

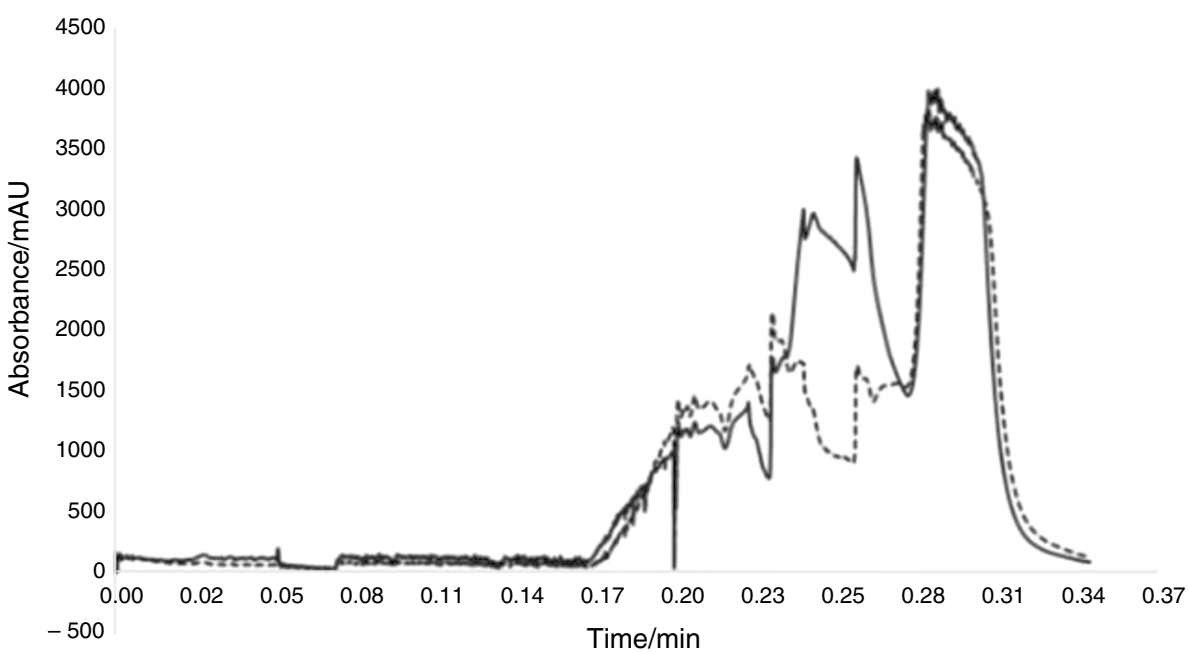


in terms of chemical composition, and they were named according to which group of bioactive compounds was dominant in them.

\subsection{Isothermal titration calorimetry}

Evaluation of receptor activation was carried out using the isothermal titration calorimetry (ITC) (MicroCal PEAQITC 200, Malvern, Worcestershire, UK). Analyses were carried out according to Grzelczyk [26], with some modifications. Calorimeter cell of a capacity $0.2 \mathrm{~mL}$ was filled with $100 \mathrm{nmol} \mathrm{L}{ }^{-1}$ PPAR- $\gamma$ solution in ultrapure water, $\mathrm{pH}$ was 4.5 , pKa range was 3.4-10 in bioactive compounds in extract coffee, the majority of the acid was undissociated, and the syringe was supplemented with titrant of degassed aqueous solutions: chlorogenic acids (CGAs) or green or light/dark roasted coffee extracts or their fractions $(10 \mathrm{mmol}$ $\mathrm{L}^{-1}$ calculated on 5-O-caffeoylquinic acid) or 15-deoxy$\Delta$ 12,14-prostaglandin J2-an "in vivo" human ligand of PPAR- $\gamma\left(20 \mathrm{nmol} \mathrm{L}^{-1}\right)$. Measurements were carried out at $36.6 \pm 0.1{ }^{\circ} \mathrm{C}$ with a continuous string (307 rpm), a maximum number of injections of $4 \mu \mathrm{L}$ volume were 6 , and the duration of all analysis was $15 \mathrm{~min}$. The analysis was carried out using ITC, and exothermic or endothermic interactions were recorded, when the binding of compounds in the active site of receptor occurred, shown as raw data of heat in $\mu \mathrm{cal} \mathrm{s}{ }^{-1}$ against time. The plot shows the heat of interactions between PPAR- $\gamma$ and GCAs/caffeine and coffee extracts or their isolates (Figs. 2-4). During the experiments enthalpy $(\Delta H)$, Gibbs free energy was described also as affinity $(\Delta G)$, and entropy $(\Delta S)$ changes have been determined, as well as dissociation constant $\left(K_{\mathrm{D}}\right)$ and binding constant $\left(K_{\mathrm{A}}\right)$. The $\Delta H, \Delta G, K_{\mathrm{D}}, K_{\mathrm{A}}, \Delta H$ and $\Delta S$ were calculated from the ITC titration nonlinear least-squares saturation curve fitting carried out in MicroCal PEAQ-ITC200 software. Complex stability constants $\left(K_{\mathrm{A}}\right.$ and $\left.K_{\mathrm{D}}\right)$ provide general information about the complex stability. They allow recognizing which of the complexes is more durable. It is a parameter that can be calculated based on calorimetric titration data, and the values depend on the temperature, the components contained in the solution, as well as the $\mathrm{pH}$. The $\Delta \mathrm{G}$ was calculated from the Gibbs equation [27, 28].

\section{Molecular modeling}

Molecular docking simulations of the PPAR- $\gamma$ receptor with different bioactive compounds from coffee allow prediction of interactions such as hydrophobic, van der Waals, hydrogen bonds, the affinity of reagents to indicate the most preferred and stable complexes of bioactive compounds with PPAR- $\gamma$ [28]. The crystal structures of the human PPAR- $\gamma$ (2PRG) were taken from the Protein Data Bank (PDB) database (https://www.rcsb.org/pdb). In the next stage, a full-atom model of the receptor was prepared. Bond orders were assigned, hydrogen atoms were added, and cap termini were included with the Protein Preparation Wizard module available in Maestro. The state of protonation was determined for all side chains (PROPKA3.1.). The chemical structures of CGAs and caffeine molecules were built up and fully optimized (B3LYP/ 6-31+G dip) [29, 30]. The docking of coffee bioactive compounds to the prepared receptor structure model was performed with the AutoDock Vina docking software using default configuration parameters. The size of the grid box for ligand docking was set to extend $120 \AA$ in each direction from the geometric center of each individual docking simulation. The scoring function in Vina considers the Lennard-Jones (LJ) term, hydrogen bonds (H bonds), electrostatic interactions, hydrophobic stabilization, entropic penalty due to the number of rotatable bonds and the internal energy of the ligand [30-32].

\section{Statistical analysis}

Light and dark roasting was conducted independently three times, and the analyses of each compound or extract, or fraction were carried out in triplicate. Statistical analysis was based on the determination of the average values of nine measurements and their standard deviation, as well as one-way ANOVA (analysis of variation), using Statistic 10.0 software at the significance level $P<0.05$.

\section{Results and discussion}

\section{Characterization of complexes of chlorogenic acids, caffeine, caffeic and ferulic acid with PPAR- $\gamma$}

Coffee is a beverage consumed all over the world because of known health-promoting properties; however, there are still no recommendations, which coffee should be drunk: green or roasted, if roasted, to what extent and what species. In our research, we checked whether the compounds contained in coffee are potential activators of the PPAR- $\gamma$ receptor to help prevention and therapy of T2DM. Therefore, in the first stage of research we used ITC tests and molecular docking simulation of selected compounds found in coffee beans, especially chlorogenic acids, caffeine, caffeic and ferulic acids. The determination of binding affinity was carried by using isothermal titrimetric calorimetry method, specifying thermodynamic parameters of interaction shown in Table 1. In order to eliminate errors in fitting, the first data points were omitted. The protein-ligand interactions detected directly based on the change in intrinsic heat, binding enthalpy of the reaction, were shown on the curves. The direct titration of CGAs into PPAR- $\gamma$ was mostly an exothermic process, which was confirmed by negative 
(a)

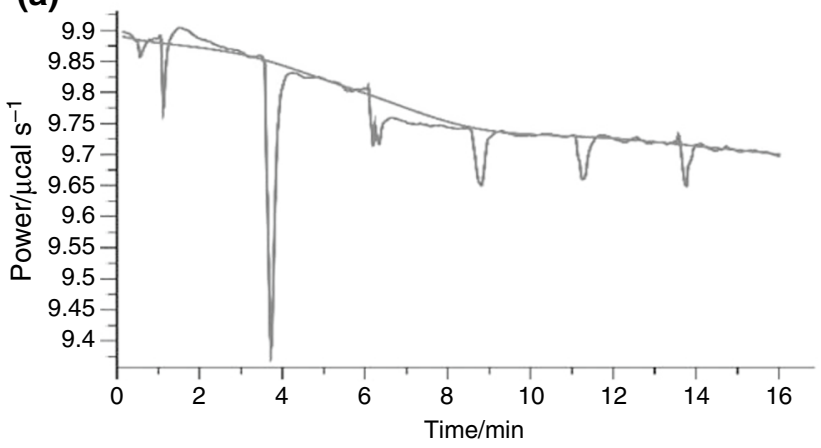

(c)

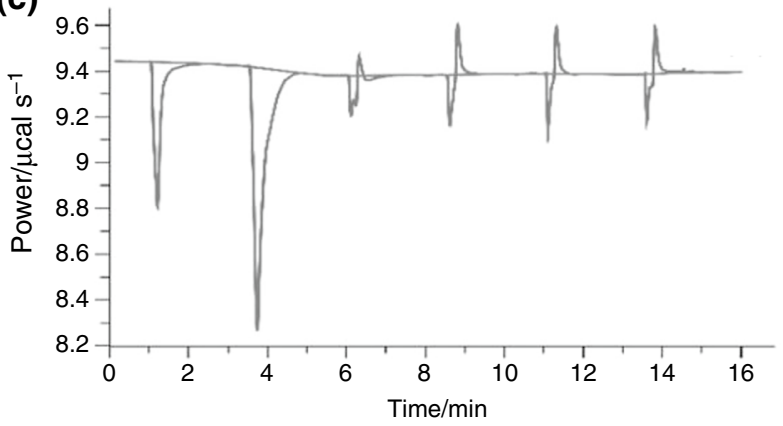

(e)

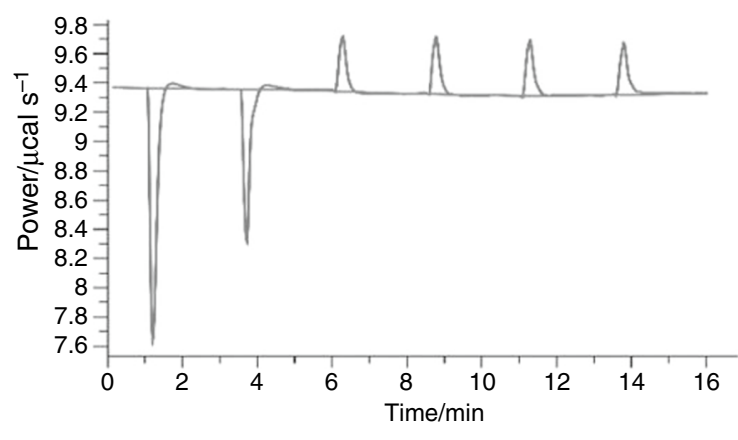

(b)

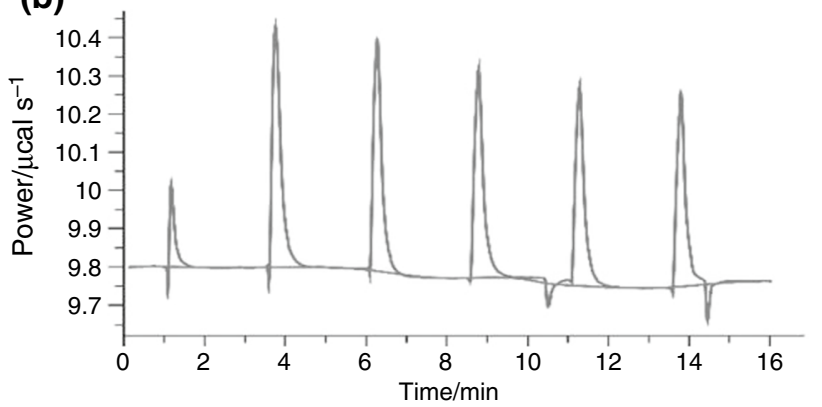

(d)

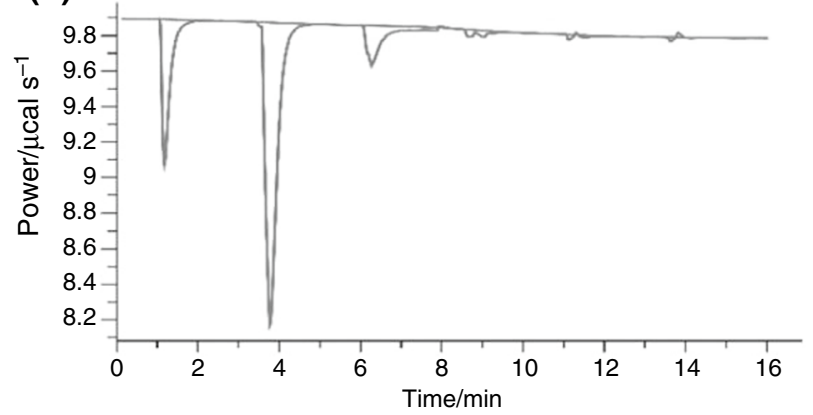

(f)

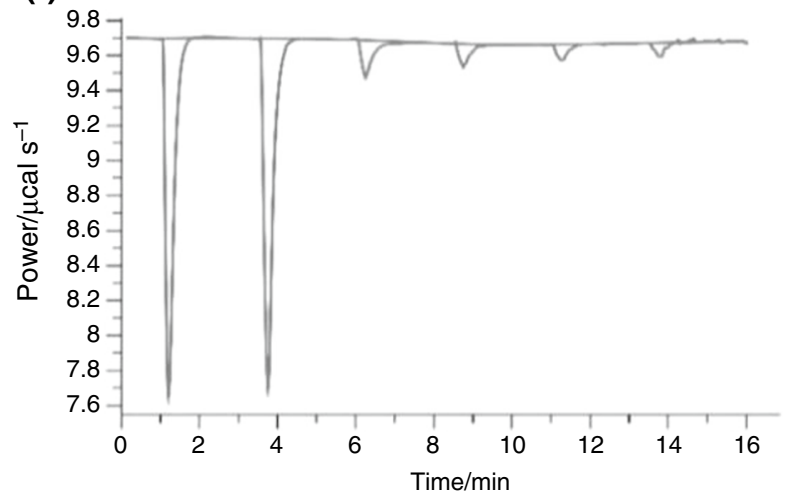

Fig. 2 ITC raw data of interactions of PPAR- $\gamma$ with: a 15-deoxy- $\Delta 12,14$-prostaglandin $\mathrm{J} 2$; b caffeine; c ferulic acid; d caffeic acid; e 3-O-caffeoylquinic acid; f dihydrocaffeic acid (a metabolite of CGAs)

(a)

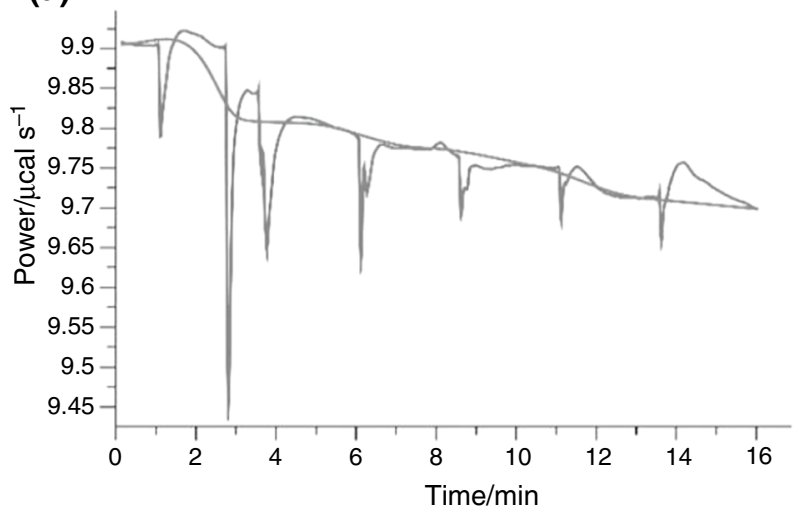

(b)

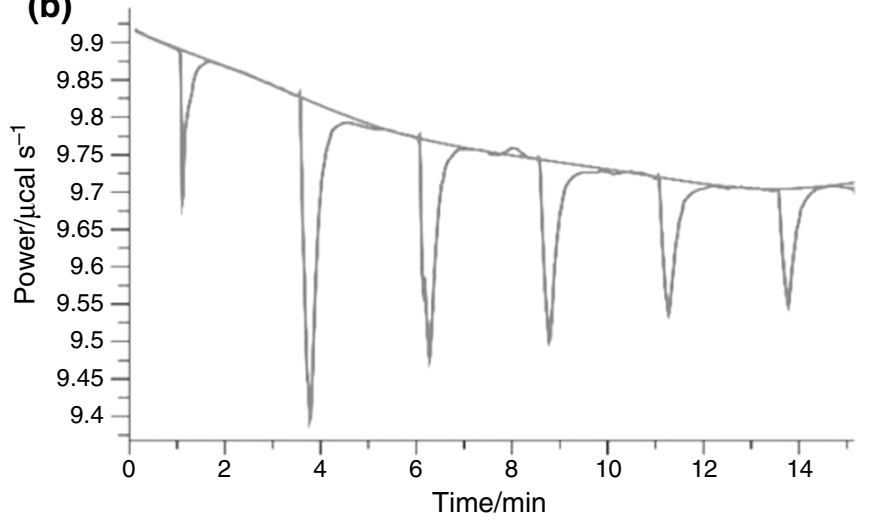

Fig. 3 ITC raw data of interactions of PPAR- $\gamma$ with coffee extracts: a green Arabica; $\mathbf{b}$ dark roasted Arabica 
(a)

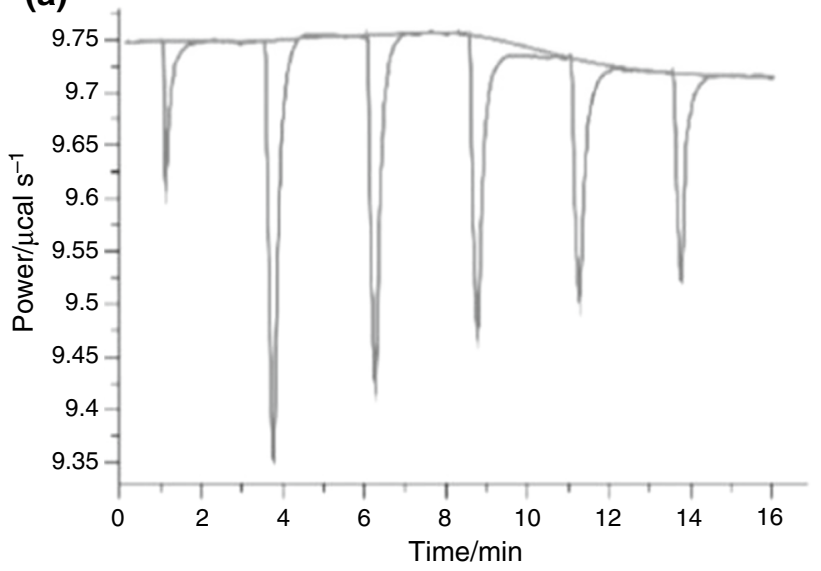

(b)

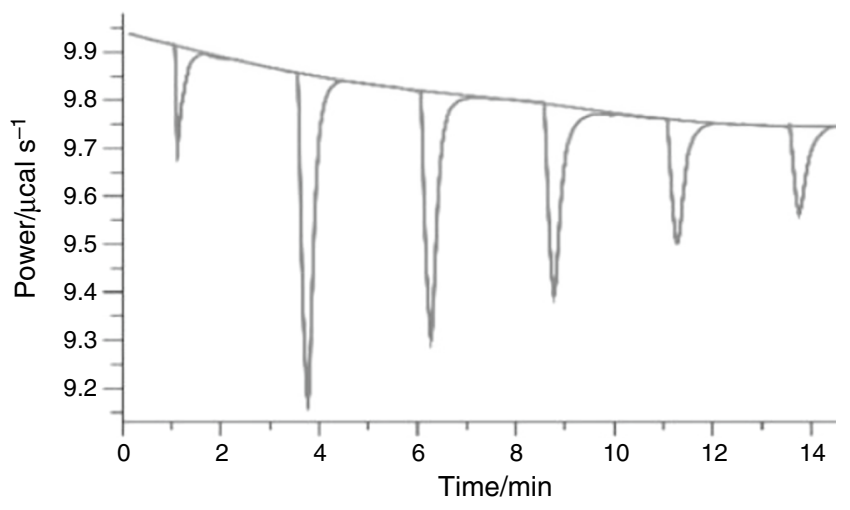

Fig. 4 ITC raw data of interactions of PPAR- $\gamma$ with isolated fractions from coffee extracts: green Robusta: a monochlorogenic acids; $\mathbf{b}$ dichlorogenic acids

Table 1 Parameters of interactions between PPAR- $\gamma$ and chlorogenic acids or caffeine

\begin{tabular}{|c|c|c|c|c|c|c|}
\hline Compound & $N$ & $K_{\mathrm{D}} / \mu \mathrm{mol} \mathrm{L} \mathrm{L}^{-1}$ & $K_{\mathrm{A}} \cdot 10^{4} / \mathrm{L} \mathrm{mol}^{-1}$ & $\Delta H / \mathrm{kJ} \mathrm{mol}^{-1}$ & $\Delta G / \mathrm{kJ} \mathrm{mol}^{-1}$ & $\Delta S / \mathrm{J} \mathrm{mol}^{-1} \mathrm{~K}^{-1}$ \\
\hline Caffeic acid & 1 & $2.21 \pm 0.0$ & $46.2 \pm 1.3$ & $-9.0 \pm 0.1$ & $-33.6 \pm 1.3$ & $79.4 \pm 0.2$ \\
\hline Ferulic acid & 1 & $2.22 \pm 0.0$ & $45.5 \pm 1.2$ & $-9.2 \pm 0.1$ & $-33.5 \pm 1.1$ & $78.6 \pm 0.2$ \\
\hline 3-O-Caffeoylquinic acid & 1 & $2.23 \pm 0.0$ & $44.4 \pm 1.1$ & $-9.3 \pm 0.1$ & $-33.5 \pm 1.5$ & $78.0 \pm 0.3$ \\
\hline 5-O-Caffeoylquinic acid & 1 & $0.27 \pm 0.0$ & $37.0 \pm 1.4$ & $-8.2 \pm 0.9$ & $-27.1 \pm 1.4$ & $61.0 \pm 1.3$ \\
\hline 4-O-Caffeoylquinic acid & 1 & $0.19 \pm 0.0$ & $52.6 \pm 1.2$ & $-8.7 \pm 2.3$ & $-28.0 \pm 1.2$ & $62.3 \pm 1.4$ \\
\hline 3,5-Di- $O$-caffeoylquinic acid & 1 & $0.19 \pm 0.0$ & $52.6 \pm 1.3$ & $-8.9 \pm 2.9$ & $-28.0 \pm 1.4$ & $61.4 \pm 1.1^{\mathrm{c}}$ \\
\hline 4,5-Di- $O$-caffeoylquinic acid & 1 & $0.195 \pm 0.0$ & $51.2 \pm 14$ & $-8.0 \pm 5.3$ & $-27.9 \pm 1.6$ & $64.3 \pm 1.5^{\mathrm{c}}$ \\
\hline Dihydrocaffeic acid & 1 & $2.1 \pm 0.0$ & $47.6 \pm 1.3$ & $-30.3 \pm 3.1^{\mathrm{b}}$ & $-33.7 \pm 1.1$ & $10.9 \pm 0.2$ \\
\hline Caffeine & 1 & $0.2 \pm 0.0^{\mathrm{a}}$ & $476 \pm 3.2^{\mathrm{b}}$ & $1.0 \pm 0.0$ & $-45.6 \pm 1.3$ & $150.6 \pm 0.4$ \\
\hline 15-Deoxy- $\Delta 12,14$-prostaglandin & 1 & $<1 * 10^{-6 \mathrm{a}}$ & $<1 * 10^{12 b}$ & $-8.6 \pm 0.1$ & $-71.1 \pm 1.1^{\mathrm{a}}$ & $201.7 \pm 0.5^{\mathrm{b}}$ \\
\hline
\end{tabular}

The solvent is water. Measurements were carried out at $36.6 \pm 0.1^{\circ} \mathrm{C}$. Values are expressed as mean value $\pm \mathrm{SD} ; n=9$; different letters in one row correspond to significant differences $(P<0.05)$

changes in reaction enthalpy $\Delta H$, and only caffeine showed a different energy effect (endothermic) showing the $\Delta H$ at around $1.01 \mathrm{~kJ} \mathrm{~mol}^{-1}$ (Fig. 2) [33, 34].

Observing protein-ligand interaction, we can see that the stoichiometry of binding hydroxycinnamic and chlorogenic acids and 15-deoxy- $\Delta$ 12,14-prostaglandin with PPAR- $\gamma$ amounts $1: 1$ and the data were therefore fitted with the 1:1 reaction model by ITC Analysis software. Stoichiometry $n=1$ gives us information that we have one binding site. The parameter $\mathrm{n}$ accounts for the fact that $\mathrm{n}$ ligand molecules can interact simultaneously with the macromolecule. Which means, that a receptor have typical one catalytic pocket of active site [35]. Among coffee components, ITC analysis showed a high PPAR- $\gamma$ binding constant for caffeine 4.76 $\cdot 10^{6} \mathrm{~L} \mathrm{~mol}^{-1}$, which correlates with the most negative changes in free energy $\left(\Delta G=-45.6 \mathrm{~kJ} \mathrm{~mol}^{-1}\right)$. It was the most hydrophobic compound of tested.
Studies conducted on 3T3-L1 adipocytes by Kim and co-authors similarly showed that caffeine is a compound that can activate PPAR isomers, as it affects the activation of PGC- $1 \alpha$ and as a result inhibits adipogenesis in concentrations from 0.1 to $5 \mathrm{mmol} \mathrm{mol}^{-1}$ [36]. Our research also showed that caffeine was the most similar value of affinity and binding constant to the strong PPAR- $\gamma$ agonist, i.e., 15-deoxy- $\Delta$ 12,14-prostaglandin; however, caffeine showed a low enthalpy of complex formation $\Delta H=1.01 \mathrm{~kJ} \mathrm{~mol}^{-1}$ (Table 1, Fig. 2a, b) and $\Delta H$ for CGAs was negative in the range from $-9.04 \mathrm{~kJ} \mathrm{~mol}^{-1}$ for caffeic acid to $-30.26 \mathrm{~kJ} \mathrm{~mol}^{-1}$ for dihydrocaffeic acid (Table 1, Fig. 1b, h). Both these compounds had high receptor affinity $\Delta G=-33.6 \mathrm{~kJ} \mathrm{~mol}^{-1}$, and for caffeine, the affinity was the highest and amounted $\Delta G=-45.6 \mathrm{~kJ} \mathrm{~kJ} \mathrm{~mol}^{-1}$. Therefore, we can consider that caffeine plays the main role in the binding activation of PPARs, along with dihydrocaffeic acid, which is a metabolite of CGAs. In addition, we can see that 
entropy for all reference compounds is positive, which correlates with negative $\Delta H$ and $\Delta G$, which tells us about the possible occurrence of covalent interactions between the ligand and protein and the conformational changes in the compounds. The polyphenols contained in coffee are covalently interacted with carbohydrates, while they are non-covalently interacted with other polyphenols but also with Maillard reaction products. The result of the thermodynamic parameters of bioactive compounds in coffee, we compared with docking simulation. It confirmed it, that the bioactive compounds in coffee are characterized by covalently interactions with receptor, in particular hydrogen bonds. We can see in Fig. 5a, h that at the ferulic acid and 3-O-caffeoylquinic acid binding with active sites of the receptor, the main hydrogen is bonded with carboxyl and amino groups. These bindings were compared to the receptor ligand widely described in the literature: 15 -deoxy- $\Delta 12,14$-PGJ2, which binds to the receptor, throughout covalent interactions at the active site of receptor and forms mostly stronger complex. However, we must not forget about non-covalent binding, mostly by pi-pi and hydrophobic interactions, which may additionally affect the stabilization of the complex [37-45]. Only with caffeine, we can see that $\Delta H$ and $\Delta S$ are positive with negative $\Delta G$, which says that binding to the receptor occurs through hydrophobic interactions. We have observed that chlorogenic acid isomers bind to the receptor to a similar extent depending on the number of functional groups. Therefore, during coffee fractionation, we decided to distinguish between monochlorogenic and dichlorogenic fractions. We can see from Table 1 that 3-O-caffeoylquinic acid, which is present in the largest amount in coffee beans, forms the most stable complex with the highest affinity.

In our research, we also performed a docking simulation (DS) to confirm ITC results and to characterize the ligand-binding site and type of interactions occurring between PPAR- $\gamma$ receptor and CGAs. The main interactions established between active site of PPAR- $\gamma$ and coffee compounds are presented in the chart depiction (in 2D) in Fig. 5. PPAR- $\gamma$ consists of three functional domains, of which LBD is built of 13 alpha helices and 4 beta structures and forms a ligand binding pocket that binds low molecular mass molecules such as fatty acids by hydrogen bonds [46-49]. The activation function 2 domain joins the ligand with hydrogen bonds, changing the spatial structure of LBD and connecting to the retinoid $\mathrm{X}$ receptor to form heterodimer $[49,50]$. The main bonds found at the LBD site, which is a small polar region, were hydrogen bonds and hydrophobic interactions, as shown in Fig. 5a-i. The interactions with dichlorogenic acids (Fig. 5d-f) were characterized by the largest number of hydrogen bonds (six) at ARG228A, ARG280A, SER342A, LEU340A, HIS266A and GLU343, which caused that they formed a more stable complex with the receptor (Table 1). They displayed strong intermolecular interactions, by forming two H-bonds with the key side chain amino acids of LBD: amino group of His266A and carboxyl group of Glu343A. The mainly of pi-pi interactions was placed at PHE264A with 5-O-caffeoylquinic acid. Caffeine showed the higher hydrophobic interactions at Leu330A and ARG288A sites [50].

\section{Interactions between PPAR- $\gamma$ and coffee extracts and their factions}

ITC analysis of coffee extracts showed strong effects of interaction with the receptor of compounds contained in green Arabica and Robusta, and they were characterized by the most stable complex formation, $\Delta H=-8.99 \mathrm{~kJ} \mathrm{~mol}^{-1}$ (Arabica) and $\Delta H=-6.94 \mathrm{~kJ} \mathrm{~mol}^{-1}$ (Robusta), where the highest affinity was determined as well, $\Delta G=-34.28 \mathrm{~kJ} \mathrm{~mol}^{-1}$ for Robusta and $\Delta G=-33.57 \mathrm{~kJ} \mathrm{~mol}^{-1}$, and the binding constant was the highest for green Robusta $\left(K_{\mathrm{A}}=61 \cdot 10^{4} \mathrm{~L}\right.$ $\left.\mathrm{mol}^{-1}\right)$. We can see that as with the reference compounds in coffee extracts and their fraction, entropy takes positive values, which correlates with negative $\Delta H$ and $\Delta G$ and tells us that covalent interactions occur between reactants and conformational changes of the compounds occur. The affinity for the receptor decreased with the degree of coffee roasting, although the drop from light to dark roast was statistically insignificant $(P>0.05)$ (Table 2). This indicates that during coffee roasting, the polyphenol compounds bind non-covalently with Maillard reaction products, suggesting that receptor binds mainly through hydrogen bonds [51].

It is related to the content of hydroxycinnamic and chlorogenic acids as well as caffeine in coffee extracts. Robusta green coffee has higher levels of all these compounds; according to Budryn et al., the total chlorogenic acids were

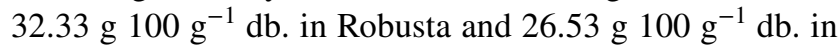
Arabica extracts [28]. It can be concluded that green coffee is a better PPAR- $\gamma$ activator and more efficiently inhibits adipocytes growth [25]. Chlorogenic acids act similarly to the known in DM2T treatment, i.e., rosiglitazone, by inhibiting the differentiation of Pref 1 adipocytes and regulating expression of genes associated with lipid synthesis $[52,53]$.

In the next stage of studies, we decided to check which coffee fraction has the highest affinity for the receptor. We obtained and collected fractions of monochlorogenic acids (5-O-caffeoylquinic acid, 3- $O$-caffeoylqunic acid, 4- $O$-caffeoylqunic acid), dichlorogenic acids (3,4-O-dicaffeoylquinic acid, 3,5-O-dicaffeoylquinic acid and 4,5-O-dicaffeoylquinic acid) and caffeine by $\mathrm{CPC}$ purification, and ITC analysis was used to determine thermodynamic parameters, which are presented in Table 3 and Fig. 4.

Research with the use of ITC demonstrated the binding constant $\mathrm{K}_{\mathrm{A}}$ of complexes between PPAR- $\gamma$ and isolated fractions of coffee extracts in the range from 10.9 to $108.6 \cdot 10^{4} \mathrm{~L} \mathrm{~mol}^{-1}$ for monochlorogenic acids from light 
(a)

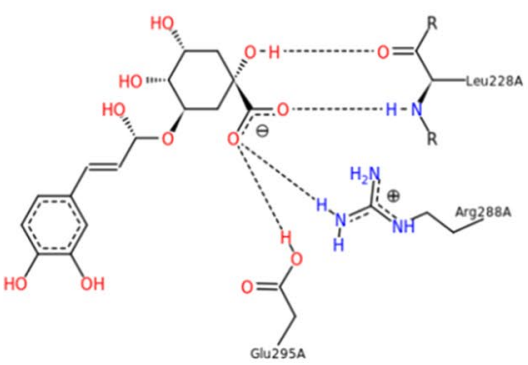

(d)

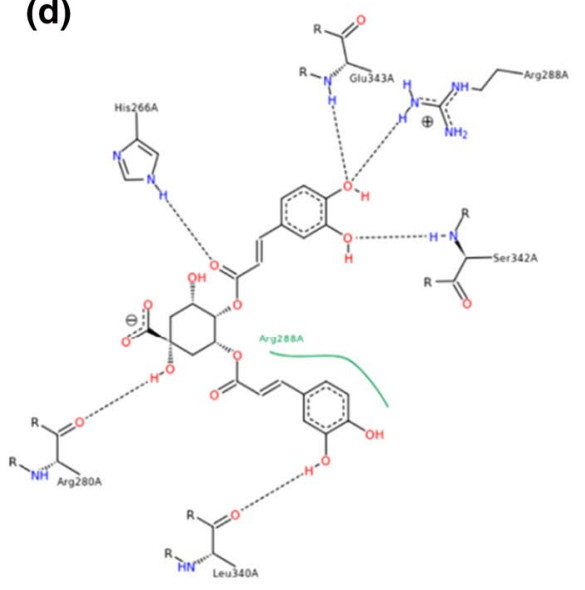

(g)

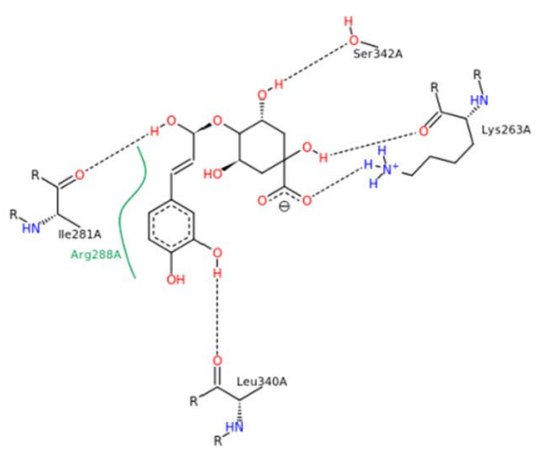

(b)

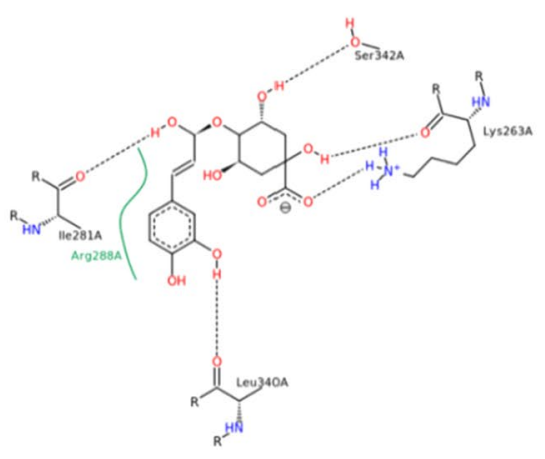

(e)

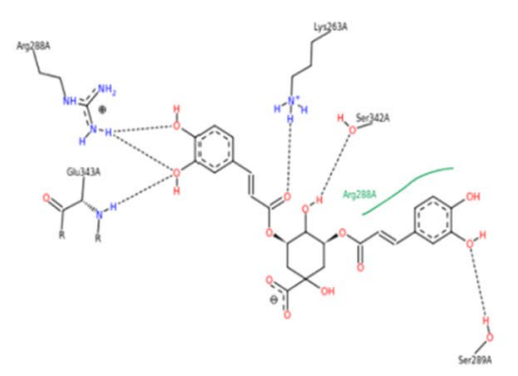

(h)

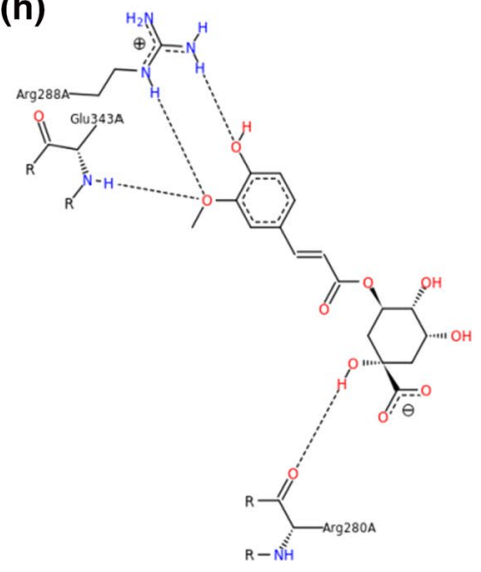

(c)

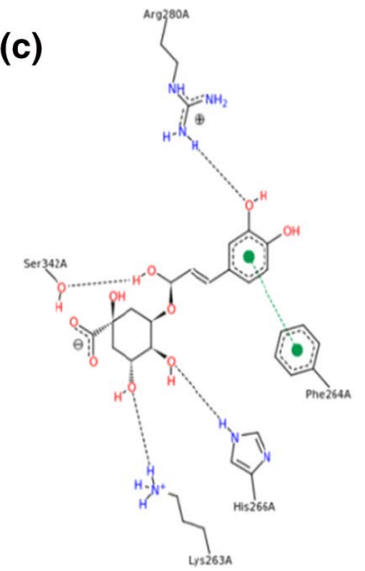

(f)

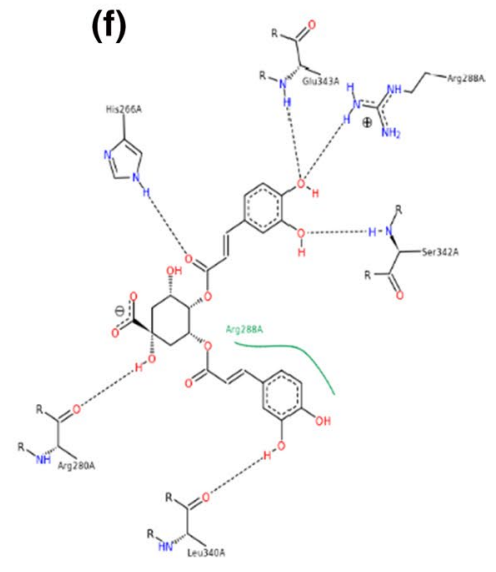

(i)

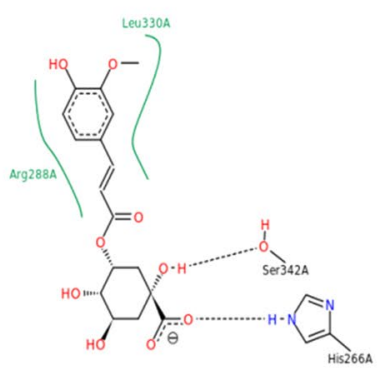

Fig. 5 Depiction (in 2D) of the main interactions established between active site of PPAR- $\gamma$ and a 3- $O$-caffeoylquinic acid; b 4 - $O$-caffeoylquinic acid; c 5- $O$-caffeoylquinic acid; d 3,4-di$O$-caffeoylquinic acid; e 3,5-di- $O$-caffeoylquinic acid; f 4,5-di-

roasted Robusta and caffeine fraction from dark roasted Arabica, respectively. The positive $\Delta S$ and negative $\Delta G$ indicate conformational changes after binding at the LBD
$O$-caffeoylquinic acid; $\mathbf{g}$ caffeic acid; $\mathbf{h}$ ferulic acid; $\mathbf{i}$ caffeine. Continuous green lines represent hydrophobic interactions, while black dashed lines show hydrogen bonds and green dashed lines pi-pi interactions

part of the receptor and strong hydrogen as well as pi-pi bond formation. The enthalpy changes $\Delta H$ resulting from interactions between PPAR- $\gamma$ and isolated fractions of 
Table 2 Parameters of interactions between PPAR- $\gamma$ and coffee extracts

\begin{tabular}{lrllll}
\hline Coffee extract & \multicolumn{1}{c}{$K_{\mathrm{D}} / \mu \mathrm{mol} \mathrm{L}$} & \multicolumn{1}{c}{$K_{\mathrm{A}} \cdot 10^{4} / \mathrm{L} \mathrm{mol}^{-1}$} & $\Delta H / \mathrm{kJ} \mathrm{mol}^{-1}$ & $\Delta G / \mathrm{kJ} \mathrm{mol}^{-1}$ & $\Delta S / \mathrm{J} \mathrm{mol}^{-1} \mathrm{~K}^{-1}$ \\
\hline Green Arabica & $2.21 \pm 0.0$ & $46.2 \pm 1.3$ & $-8.9 \pm 1.1^{\mathrm{a}}$ & $-33.6 \pm 2.4$ & $79.7 \pm 0.1$ \\
Light roasted Arabica & $0.040 \pm 0.2$ & $52.4 \pm 1.3$ & $-1.9 \pm 0.4$ & $-8.3 \pm 1.3^{\mathrm{a}}$ & $20.6 \pm 0.4^{\mathrm{b}}$ \\
Dark roasted Arabica & $0.043 \pm 0.5$ & $51.5 \pm 1.3$ & $-1.9 \pm 0.4$ & $-8.1 \pm 1.4^{\mathrm{a}}$ & $20.0 \pm 0.3^{\mathrm{b}}$ \\
Green Robusta & $1.63 \pm 0.2$ & $61.0 \pm 1.2$ & $-6.9 \pm 1.1^{\mathrm{b}}$ & $-34.3 \pm 2.4$ & $88.5 \pm 0.1$ \\
Light roasted Robusta & $0.019 \pm 0.1$ & $50.7 \pm 1.3$ & $-1.9 \pm 0.4$ & $-10.1 \pm 1.2^{\mathrm{a}}$ & $26.5 \pm 0.4^{\mathrm{b}}$ \\
Dark roasted Robusta & $0.021 \pm 0.3$ & $48.7 \pm 1.2$ & $-2.0 \pm 0.3$ & $-10.0 \pm 1.2^{\mathrm{a}}$ & $25.9 \pm 0.4^{\mathrm{b}}$
\end{tabular}

The solvent is water. Measurements were carried out at $36.6 \pm 0.1{ }^{\circ} \mathrm{C}$. Values are expressed as mean value $\pm \mathrm{SD} ; n=9$; different letters in one row correspond to significant differences $(P<0.05)$

Table 3 Parameters of interactions between PPAR- $\gamma$ and isolated fractions of coffee extracts

\begin{tabular}{|c|c|c|c|c|c|}
\hline $\begin{array}{l}\text { Isolated fractions of coffee extracts } \\
10 \mathrm{mmol} \mathrm{L}^{-1} \text { as chlorogenic acid }\end{array}$ & $K_{\mathrm{D}} / \mu \mathrm{mol} \mathrm{L}{ }^{-1}$ & $K_{\mathrm{A}} \cdot 10^{4} / \mathrm{L} \mathrm{mol}^{-1}$ & $\Delta H / \mathrm{kJ} \mathrm{mol}^{-1}$ & $\Delta G / \mathrm{kJ}$ mol & $\Delta S / \mathrm{J} \mathrm{mol}^{-1} \mathrm{~K}^{-1}$ \\
\hline \multicolumn{6}{|l|}{ Green Robusta } \\
\hline Monochlorogenic acids & $1.9 \pm 0.0$ & $53.0 \pm 5.4$ & $-7.8 \pm 0.0$ & $-34.0 \pm 0.1$ & $84.4 \pm 0.0$ \\
\hline Dichlorogenic acids & $2.1 \pm 0.0$ & $47.6 \pm 3.2$ & $-8.7 \pm 0.0$ & $-33.7 \pm 0.1^{\mathrm{c}}$ & $80.6 \pm 0.0$ \\
\hline Caffeine & $2.1 \pm 1.5$ & $47.6 \pm 3.1$ & $-8.7 \pm 0.0$ & $-33.7 \pm 0.1^{\mathrm{c}}$ & $80.6 \pm 0.0^{\mathrm{a}}$ \\
\hline \multicolumn{6}{|l|}{ Light roasted Robusta } \\
\hline Monochlorogenic acids & $1.9 \pm 0.0$ & $51.0 \pm 7.2$ & $-8.1 \pm 0.0^{\mathrm{a}, \mathrm{b}}$ & $-33.9 \pm 0.2$ & $83.4 \pm 0.0$ \\
\hline Dichlorogenic acids & $2.1 \pm 0.0$ & $10.9 \pm 4.1^{\mathrm{b}}$ & $-8.6 \pm 0.0$ & $-33.7 \pm 0.1^{\mathrm{d}}$ & $80.9 \pm 0.0$ \\
\hline Caffeine & $5.2 \pm 0.0^{\mathrm{a}}$ & $19.1 \pm 3.3^{\mathrm{b}}$ & $-7.5 \pm 0.0$ & $-31.4 \pm 0.1^{\mathrm{d}}$ & $76.9 \pm 0.0$ \\
\hline \multicolumn{6}{|l|}{ Dark roasted Robusta } \\
\hline Monochlorogenic acids & $1.8 \pm 0.0$ & $54.6 \pm 7.3$ & $-7.6 \pm 0.0$ & $-34.0 \pm 0.1$ & $85.4 \pm 0.0$ \\
\hline Dichlorogenic acids & $1.9 \pm 0.0$ & $50.1 \pm 7.4$ & $-8.2 \pm 0.0$ & $-33.9 \pm 0.1$ & $83.0 \pm 0.0$ \\
\hline Caffeine & $1.2 \pm 0.0$ & $83.3 \pm 9.1$ & $-5.1 \pm 0.0$ & $-35.1 \pm 0.1$ & $96.8 \pm 0.0$ \\
\hline \multicolumn{6}{|l|}{ Green Arabica } \\
\hline Monochlorogenic acids & $1.90 \pm 0.0$ & $52.6 \pm 5.0$ & $-7.8 \pm 0.0$ & $-33.9 \pm 0.1$ & $84.3 \pm 0.0$ \\
\hline Dichlorogenic acids & $2.06 \pm 0.0$ & $48.8 \pm 3.6$ & $-8.5 \pm 0.0$ & $-33.7 \pm 0.1$ & $81.4 \pm 0.0$ \\
\hline Caffeine & $0.55 \pm 0.0^{\mathrm{b}}$ & $181.8 \pm 9.9^{\mathrm{a}}$ & $-2.4 \pm 0.0^{\mathrm{b}}$ & $-37.1 \pm 0.1$ & $112.0 \pm 0.0$ \\
\hline \multicolumn{6}{|l|}{ Light roasted Arabic } \\
\hline Monochlorogenic acids & $2.0 \pm 0.0$ & $50.0 \pm 3.3^{\mathrm{b}}$ & $-8.4 \pm 0.0$ & $-33.8 \pm 0.0$ & $81.9 \pm 0.0$ \\
\hline Dichlorogenic acids & $1.8 \pm 0.0$ & $55.5 \pm 4.1$ & $-7.5 \pm 0.0$ & $-34.1 \pm 0.1$ & $85.7 \pm 0.0$ \\
\hline Caffeine & $2.0 \pm 0.0$ & $50.0 \pm 4.7$ & $-8.3 \pm 0.0$ & $-33.8 \pm 0.1$ & $82.3 \pm 0.0$ \\
\hline \multicolumn{6}{|l|}{ Dark roasted Arabica } \\
\hline Monochlorogenic acids & $1.89 \pm 0.0$ & $54.0 \pm 5.0$ & $-7.7 \pm 0.0$ & $-34.0 \pm 0.1$ & $84.7 \pm 0.0$ \\
\hline Dichlorogenic acids & $1.92 \pm 0.0$ & $52.1 \pm 5.1$ & $-3.9 \pm 0.0^{\mathrm{b}}$ & $-33.9 \pm 0.1$ & $96.8 \pm 0.0$ \\
\hline Caffeine & $0.92 \pm 0.0^{\mathrm{b}}$ & $108.6 \pm 9.4^{\mathrm{a}}$ & $-8.6 \pm 0.1$ & $-35.8 \pm 0.1$ & $87.8 \pm 0.6$ \\
\hline
\end{tabular}

The solvent is water. Measurements were carried out at $36.6 \pm 0.1{ }^{\circ} \mathrm{C}$. Values are expressed as mean value $\pm \mathrm{SD} ; n=9$; different letters in one row correspond to significant differences $(P<0.05)$

coffee extracts were negative, and the reactions were exothermic; $\Delta H$ ranged from $-3.95 \mathrm{~kJ} \mathrm{~mol}^{-1}$ for dichlorogenic acids from dark roasted Arabica to $-8.71 \mathrm{~kJ} \mathrm{~mol}^{-1}$ for dichlorogenic acids from green Robusta (Table 3, Fig. 4b, r). Roasting process caused the shift of thermodynamic parameters to weaker complexes with slightly increased affinity, which may be due to the binding of free CGAs with Maillard reaction products during roasting that decreases the availability of CGAs for binding with the receptor. In contrast, the increase in caffeine binding with PPAR- $\gamma$ in dark roasted coffees resulted from greater bioavailability and less competition of degraded chlorogenic acids. It was also observed that interactions with these ligands have been characterized by highly negative values of $\Delta G$ of -31.40 and $-37.13 \mathrm{~kJ} \mathrm{~mol}^{-1}$, for Arabica and Robusta, respectively, suggesting hydrogen bond formation with LBD site of PPAR- $\gamma$. Fractions obtained from the extracts were partially purified that caused a more similar receptor affinity 
compared to whole extracts, where a reduced affinity of the extracts from light and dark roasted beans was observed. This indicates that both light and dark roasted coffee contains compounds formed during roasting that reduce receptor affinity. In the next stage, the affinity of the extracts and the fractions obtained from them after "in vitro" digestion will be studied to establish whether the action of digestive enzymes causes changes in the interactions of coffee extracts with PPAR- $\gamma$.

\section{Conclusions}

The conducted studies on the interactions of coffee extracts and their fraction as well as single bioactive coffee compounds with PPAR- $\gamma$ and on the affinity for the receptor showed that caffeine might have the most beneficial properties of binding with the protein and activating the signaling track increasing gene expression that reduces adipocytes growth. The coffee extracts, thanks to the high content of polyphenols, and in particular chlorogenic acids and caffeine, are potential agonist of PPAR- $\gamma$ regulating the glucose homeostasis and increasing the insulin sensitivity of peripheral tissues, preventing type 2 diabetes. Green coffee contains higher than roasted concentration of bioactive compounds with a potential of PPAR- $\gamma$ agonist. Light and roasted coffee contains compounds formed during roasting, decreasing the affinity for PPAR- $\gamma$, but the influence of digestion and absorption should be taken into consideration in future studies.

Acknowledgements The work is the result of the research Project No. UMO-2018/29/N/NZ9/01160 funded by the National Science Center.

Authors' contributions All authors contributed to the study conception and design. Material preparation, data collection and analysis were performed by Joanna Grzelczyk, Grażyna Budryn and Horacio Pérez-Sánchez. The first draft of the manuscript was written by Joanna Grzelczyk, and all authors commented on previous versions of the manuscript. All authors read and approved the final manuscript.

\section{Compliance with ethical standards}

Conflicts of interest The authors declare no conflict of interest.

Open Access This article is licensed under a Creative Commons Attribution 4.0 International License, which permits use, sharing, adaptation, distribution and reproduction in any medium or format, as long as you give appropriate credit to the original author(s) and the source, provide a link to the Creative Commons licence, and indicate if changes were made. The images or other third party material in this article are included in the article's Creative Commons licence, unless indicated otherwise in a credit line to the material. If material is not included in the article's Creative Commons licence and your intended use is not permitted by statutory regulation or exceeds the permitted use, you will need to obtain permission directly from the copyright holder. To view a copy of this licence, visit http://creativecommons.org/licenses/by/4.0/.

\section{References}

1. Zhang H, Pollen IT. Epigenetics variation and pathogenesis in diabetes. Curr Diab Rep. 2018;18:121-7.

2. Bedi O, Aggarwal S, Trehanpati N, Ramakrishna G, Krishan P. Molecular and pathological events involved in the pathogenesis of diabetes-associated nonalcoholic fatty liver disease. JCEH. 2018. https://doi.org/10.1016/j.jceh.2018.10.004.

3. Scholfield JD, Liu Y, Rao-Balakrishna P, Malik RA, Soran H. Diabetes dyslipidemia. Diabetes Ther. 2016;7:203-19.

4. Martinov T, Fife BT. Type 1 diabetes pathogenesis and the role of inhibitory receptors in islet tolerance. Ann NY Acad Sci. 2019. https://doi.org/10.1111/nyas.14106.

5. Johnson MB, Cerosaletti K, Flanagan SE, Buckner JH. Genetic mechanisms highlight shared pathways for the pathogenesis of polygenic type 1 diabetes and monogenic autoimmune diabetes. Curr Diab Rep. 2019;19:20.

6. Stols-Gonçalves D, Schiliró TL, Henneman P, Nieuwdorp M. Epigenetic markers and microbiota/metabolite-induced epigenetic modifications in the pathogenesis of obesity, metabolic syndrome, type 2 diabetes, and non-alcoholic fatty liver disease. Curr Diab Rep. 2019;19:31.

7. Sarqsyan A, Herman MA. Regulation of glucose production in the pathogenesis of type 2 diabetes. Curr Diab Rep. 2019;19:77-9.

8. Pearson ER. Type 2 diabetes: a multifaceted disease. Diabetologia. 2019;62:1107-12.

9. Cai Y, Zheng F. Concurrent exercise improves insulin resistance and nonalcoholic fatty liver disease by upregulating PPAR- $\gamma$ and genes involved in the beta-oxidation of fatty acids in ApoE-KO mice fed a high-fat diet. Lipids Health Dis. 2019. https://doi. org/10.1186/s12944-018-0933-z.

10. Bhargava P, Verma VK, Malik S, Khan SI, Bhatia J, Arya DS. Hesperidin regresses cardiac hypertrophy by virtue of PPAR- $\gamma$ agonistic, anti-inflammatory, antiapoptotic, and antioxidant properties. J Biochem Mol Toxicol. 2019;33:e22283.

11. Lapice E, Monticelli A, Cocozza S, Pinelli M, Cocozza S, Bruzzese D, Riccardi G, Vaccaro O. The PPAR $\gamma 2$ Pro12Ala variant is protective against progression of nephropathy in people with type 2 diabetes. J Transl Med. 2015. https://doi.org/10.1186/s1296 7-015-0448-6.

12. Mohamed WA, Schaalan MF. Antidiabetic efficacy of lactoferrin in type 2 diabetic pediatrics; controlling impact on PPAR- $\gamma$, SIRT1, and TLR4 downstream signaling pathway. Diabetol Metab Syndr. 2018. https://doi.org/10.1186/s13098-018-0390-x.

13. Sahin N, Orhan C, Erten F, Tuzcu M, Defo Deeh PB, Ozercan IH, Juturu V, Kazim S. Effects of allyl isothiocyanate on insulin resistance, oxidative stress status, and transcription factors in high-fat diet/streptozotocin-induced type 2 diabetes mellitus in rats. J Biochem Mol Toxicol. 2019;33:e22328.

14. Majid M, Masood A, Kadla SA, Hameed I, Ganai BA. Association of Pro12Ala polymorphism of peroxisome proliferator-activated receptor gamma 2 (PPAR $\gamma 2$ ) gene with type 2 diabetes mellitus in ethnic Kashmiri population. Biochem Genet. 2017;55:10-211.

15. Michalik L, Auwerx J, Berger JP, Chatterjee VK, Glass CK, Gonzalez FJ, Grimaldi PA, Kadowaki T, Lazar MA, O'Rahilly S, Palmer CN, Plutzky J, Reddy JK, Spiegelman BM, Staels B, Wahli W. International union of pharmacology. LXI. Peroxisome proliferator-activated receptors. Pharmacol Rev. 2006;58:726-41.

16. Stalin A, Irudayaraj SS, Kumar DP, Balakrishna K, Ignacimuthu S, Al-Dhabi NA, Duraipandiyan V. Identifying potential PPAR $\gamma$ agonist/partial agonist from plant molecules to control type 2 diabetes using in silico and in vivo models. Med Chem Res. 2016;25:1980-92. 
17. Chaturvedi RN, Pendem K, Patel VP, Sharma M, Malhotra S. Design, synthesis, molecular docking, and in vitro antidiabetic activity of novel PPAR $\gamma$ agonist. Chem Mon. 2018;149:2069-84.

18. Chhabra M, Sharma S. Potential role of peroxisome proliferator activated receptor gamma analogues in regulation of endothelial progenitor cells in diabetes mellitus: an overview. Diabetes Metab Syndr. 2019;13:1123-9.

19. Gim HJ, Choi YS, Li H, Kim YJ, Ryu JH, Jeon R. Identification of a novel PPAR- $\gamma$ agonist through a Scaffold tuning approach. Int J Mol Sci. 2018. https://doi.org/10.3390/ijms19103032.

20. Corrales P, Izquierdo-Lahuerta A, Medina-Gómez G. Maintenance of kidney metabolic homeostasis by PPAR gamma. Int $\mathrm{J}$ Mol Sci. 2018. https://doi.org/10.3390/ijms19072063.

21. Aoyagi R, Funakoshi-Tago M, Fujiwara Y, Tamura H. Coffee inhibits adipocyte differentiation via inactivation of PPAR $\gamma$. Biol Pham Bull. 2014;37:1820-5.

22. Babita S, Karun S, Rumani S, Kishore RS, Sarinder KD, Yukio N, Meena KS. Coffee component hydroxyl hydroquinone (HHQ) as a putative ligand for PPAR gamma and implications in breast cancer. BMC Genom. 2013. https://doi.org/10.1186/1471-2164-14-S5-S6.

23. Choi BK, Park SB, Lee DR, Lee HJ, Jin YY, Yang SH, Suh JW. Green coffee bean extract improves obesity by decreasing body fat in high-fat diet-induced obese mice. J Trop Med. 2016;9:635-43.

24. Pan MH, Tung Y, Yang G, Li S, Ho CT. Molecular mechanisms of the anti-obesity effect of bioactive compounds in tea and coffee. Food Funct. 2016;7:4481-91.

25. Budryn G, Zakłos-Szyda M, Zaczyńska D, Żyżylewicz D, Grzelczyk J, Zduńczk Z, Juśkiewicz J. Green and roasted coffee extracts as antioxidants in $\beta \mathrm{TC} 3$ cells with induced oxidative stress and lipid accumulation inhibitors in 3T3L1 cells, and their bioactivity in rats fed high fat diet. Eur Food Res Technol. 2017;243:1323-34.

26. Mishra GP, Sharma R. Identification of potential PPAR c agonists as hypoglycemic agents: molecular docking approach. Interdiscip Sci Comput Life Sci. 2016;8:220-8.

27. Haman N, Signorelli M, Duce C, Franzetti L, Fessas D. Isothermal calorimetry protocols to monitor the shelf life and aftermarket follow-up of fresh cut vegetables. JTAC. 2019;137:1673-80.

28. Vega S, Abian O, Velazquez-Campoy A. Handling complexity in biological interactions. JTTAC. 2019;138:3229-488.

29. Budryn G, Grzelczyk J, Jaśkiewicza A, Żyżelewicz D, PérezSánchez H, Cerón-Carrasco JP. Evaluation of butyrylcholinesterase inhibitory activity by chlorogenic acids and coffee extracts assed in ITC and docking simulation models. Int J Food Sci Technol. 2018;108:268-77.

30. Feng XY, Jia WQ, Liu X, Jing Z, Liu YY, Xu WR, Cheng XC. Identification of novel PPAR $\alpha / \gamma$ dual agonists by virtual screening, ADMET prediction and molecular dynamics simulations. Comput Biol Chem. 2019;78:178-89.

31. Sastry GM, Adzhigirey M, Day T, Annabhimoju R, Sherman W. Protein and ligand preparation: Parameters, protocols, and influence on virtual screening enrichments. J Comput Aid Mol Des. 2013;27:221-34

32. Trott O, Olson AJ. AutoDock Vina: improving the speed and accuracy of docking with a new scoring function, efficient optimization, and multithreading. J Comput Chem. 2010;31:455-61.

33. Nguyen TH, Rustenburg AS, Krimmer SG, Zhang H, Clark JD, Novick PA, Branson K, Pande VS, Chodera JD, Minh DDL. Bayesian analysis of isothermal titration calorimetry for binding thermodynamics. PLoS ONE. 2018;13(9):e0203224.

34. Paketurytė V, Linkuvienè V, Krainer G, Chen WY, Matulis D. Repeatability, precision, and accuracy of the enthalpies and Gibbs energies of a protein-ligand binding reaction measured by isothermal titration calorimetry. Eur Biophys J. 2019;48:139-52.

35. López-Garzón CS, Straathof AJJ. Recovery of carboxylic acids produced by fermentation. Biotechnol Adv. 2014;32:873-904.
36. Kim AR, Yoon BK, Park H, Seok JW, Choi H, Yu JH, Choi Y, Song SJ, Kim A, Kim JW. Caffeine inhibits adipogenesis through modulation of mitotic clonal expansion and the AKT/GSK3 pathway in 3T3-L1 adipocytes. BMB Rep. 2016;49:111-5.

37. Li M, Pascual G, Glass CK. Peroxisome proliferator-activated receptor $\gamma$-dependent repression of the inducible nitric oxide synthase gene. Mol Cell Biol. 2000;20:4699-707.

38. Egawa D, Itoh T, Yamamoto K. Characterization of covalent bond formation between PPAR $\gamma$ and oxo-fatty acids. Bioconjug Chem. 2015;26(4):690-8.

39. Waku T, Shiraki T, Oyama T, Fujimoto Y, Maebara K, Kamiya N, Jingami H, Morikawa K. Structural insight into PPARgamma activation through covalent modification with endogenous fatty acids. J Mol Biol. 2009. https://doi.org/10.1016/j.jmb.2008.10.039.

40. Itoh T, Fairall L, Amin K, Inaba Y, Szanto A, Balint BL, Nagy L, Yamamoto K, Schwabe JW. Structural basis for the activation of PPAR $\gamma$ by oxidized fatty acids. Nat Struct Mol Biol. 2008;15(9):924-31.

41. Jang JY, Kim H, Kim HJ, Suh SW, Park SB, Han BW. Structural basis for the inhibitory effects of a novel reversible covalent ligand on PPAR $\gamma$ phosphorylation. Sci Rep. 2019. https://doi. org/10.1038/s41598-019-47672-w.

42. Reddy T, Lakshmi SP, Banno A, Reddy RC. Dentification and molecular characterization of peroxisome proliferatoractivated receptor $\delta$ as a novel target for covalent modification by 15-deoxy- $\Delta$ 12,14 -prostaglandin J 2 . ACS Chem Biol. 2018;13(12):3269-78.

43. Shashni B, Sharma K, Singh R, Sakharkar KR, Dhillon SK, Nagasaki Y, Sakharkar MK. Coffee component hydroxyl hydroquinone (HHQ) as a putative ligand for PPAR gamma and implications in breast cancer. BMC Genom. 2013. https://doi. org/10.1186/1471-2164-14-S5-S6.

44. Brust R, Shang J, Fuhrmann J, Mosure SA, Bass J, Cano A, Heidari Z, Chrisman IM, Nemetchek MD, Blayo AL, Griffin PR, Kamenecka TM, Hughes TS, Kojetin DK. A structural mechanism for directing inverse agonism of PPAR $\gamma$. Nat Commun. 2018. https://doi.org/10.1038/s41467-018-07133-w.

45. Xia Z, Howard AY. PPAR and immune system-what do we know? Int Immunopharmacol. 2002;2(8):1029-44.

46. Martinez-Gonzalez AI, Díaz-Sánchez ÁG, Rosa LA, VargasRequena CL, Bustos-Jaimes I, Alvarez-Parrilla AE. Polyphenolic compounds and digestive enzymes: in vitro non-covalent interactions. Molecules. 2017. https://doi.org/10.3390/molecules220406 69.

47. Sokołowska M, Kowalski ML, Pawliczak R. Peroxisome proliferator-activated receptors-gamma (PPAR-gamma) and their role in immunoregulation and inflammation control. Postepy Hig Med Dosw. 2005;59:472-84.

48. Li Z, Zhou Z, Deng F, Li Y, Zhang D, Zhang L. Design, synthesis, and biological evaluation of novel pan agonists of FFA1, PPAR $\gamma$ and PPARס. Eur J Med Chem. 2018;159:267-76.

49. Laghezza A, Piemontese L, Tortorella P, Loiodiece F. An update about the crucial role of stereochemistry on the effects of peroxisome proliferator-activated receptor ligands. Eur J Med Chem. 2019;176:326-42.

50. Siraj FM, Natarajan S, Hug MA, Kim YJ, Yang DC. Structural investigation of ginsenoside Rf with PPAR $\gamma$ major transcriptional factor of adipogenesis and its impact on adipocyte. J Ginseng Res. 2015;39:141-7.

51. Muralikumar S, Vetrivel U, Narayanasamy A, Das UN. Probing the intermolecular interactions of PPAR $\gamma$-LBD with polyunsaturated fatty acids and their anti-inflammatory metabolites to infer most potential binding moieties. Lipids Health Dis. 2017;16:17.

52. Ali M, Homann T, Kreisel J, Khalil M, Puhlmann R, Kruse HP, Rawel H. Characterization and modeling of the interactions 
between coffee storage proteins and phenolic compounds. J Agric Food Chem. 2012;60(46):11601-9.

53. Peng SG, Pang YL, Zhu Q, Kang JH, Liu MX, Wang Z. Chlorogenic acid functions as a novel agonist of PPAR- $\gamma 2$ during the differentiation of mouse 3T3-L1 preadipocytes. Biomed Res Int. 2018;3:1-14.
Publisher's Note Springer Nature remains neutral with regard to jurisdictional claims in published maps and institutional affiliations. 